scorched in preparation, either fruited or produced abortive fruit bodies, while no fruiting was observed in other cultures. The scorched condition of the medium would of course give rise to substances not generally present in the culture medium, and it is suggested that this condition of nutrition may have been the determining factor. It is also of interest to note that the fruit bodies from which the spores were obtained were

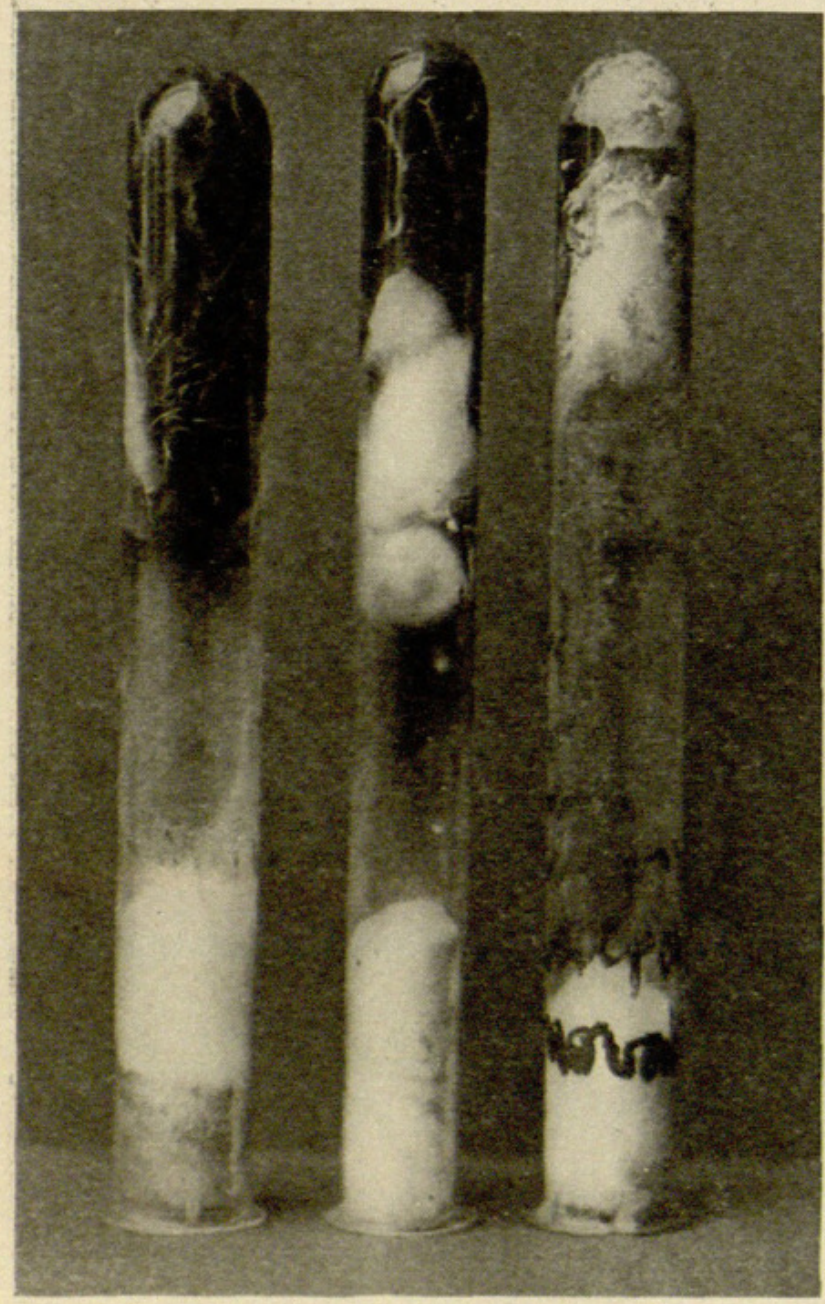

FIG. 3 frozen solid when collected, which did not appear to injure the viability of the spores.

Cultures of another very interesting agaric were obtained from the pathologist of the Forest Products Laboratory at Madison, Wisconsin, namely Armillaria mellea Vahl. This species forms a whitish mycelium which soon turns to a dark brown. The interesting feature, however, is the formation of the so-called "rhizomorphs." These are described as appearing in nature as shining black strands often resembling the roots of the host. They appear soon after inoculation on agar cultures, ramifying throughout the substratum. Here, however, they are of a shining light gray color, and are flat and ribbon-like, often

branching dichotomously (fig. 3). Upon pentrating to a free surface these rhizomorphs immediately give rise to the ordinary vegetative mycelium.- V. H. Young, University of Wisconsin, Madison.

\title{
THE AMOUNT OF BARE GROUND IN SOME MOUNTAIN GRASSLANDS
}

In July I9I I the writer staked out a series of I9 quadrats for study of the grassland of a mountain park at Tolland, Colorado. In that year collections were begun and censuses of some of the quadrats made. The plan was adopted of estimating at intervals the percentage composi- 
tion of each quadrat. Early in rgı 2 more detailed work was undertaken, all findings being recorded on catalogue cards. Each time a quadrat was examined an e timate ${ }^{2}$ was made of the percentage of bare ground. Since there seem to be no published records of such studies in our mountains, it has occurred to the writer that a brief note on the subject would be of interest.

The mountain park under consideration is a small glaciated valley in the Rocky Mountains at an altitude of about 9000 feet. The climate is cold, the July mean being about $56^{\circ} \mathrm{F}$. Most of the park has a coarse soil of decomposed granite. Upon this is a xerophytic grassland vegetation. In certain places, however, particularly at points along the margins of creeks or ponds and in glacial sinks, a mesophytic grassland develops. This may be spoken of as "meadow." Here the soil has a considerable amount of humus derived from washings of adjacent slopes. Of the I9 quadrats, I 7 are in dry grassland and 2 in meadow.

The data presented (tables I and II) are arranged according to time of year. Although the observations were made in two seasons, no doubt they show normal conditions, since both years had about the usual precipitation and were not greatly different in temperatures.

TABLE I

PERCENTAGE OF BARE GROUND IN DRY GRASSLAND

\begin{tabular}{|c|c|c|c|c|c|c|}
\hline Quadrat & $\underset{\text { I91 } 2}{\text { May } 30,}$ & $\begin{array}{c}\text { June I } 2, \\
\text { I913 }^{2}\end{array}$ & $\begin{array}{c}\text { June } 28, \\
\text { I9I } 3\end{array}$ & $\begin{array}{l}\text { July r2, } \\
\text { I913 }\end{array}$ & $\begin{array}{c}\text { July } 26, \\
\text { rgri3 }\end{array}$ & $\begin{array}{l}\text { Sept. I, } \\
\text { rgI2 }\end{array}$ \\
\hline 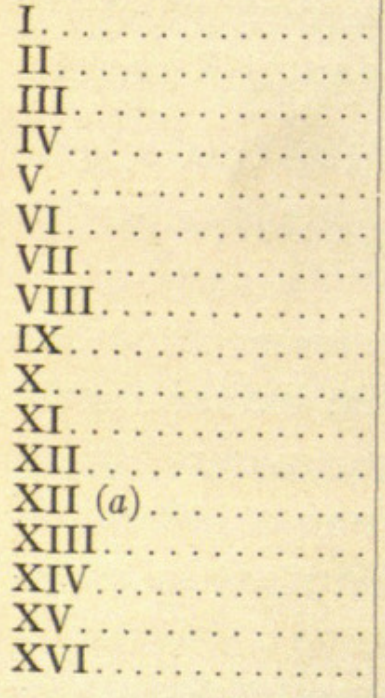 & $\begin{array}{l}75 \\
60 \\
63 \\
50 \\
60 \\
60 \\
50 \\
70 \\
64 \\
63 \\
80 \\
50 \\
60 \\
50 \\
60 \\
50 \\
60\end{array}$ & $\begin{array}{r}60 \\
49 \\
42 \\
20 \\
55 \\
50 \\
58 \\
38 \\
55 \\
30 \\
25 \\
75 \\
\ldots \ldots \\
40 \\
\ldots \ldots \\
\ldots \ldots\end{array}$ & 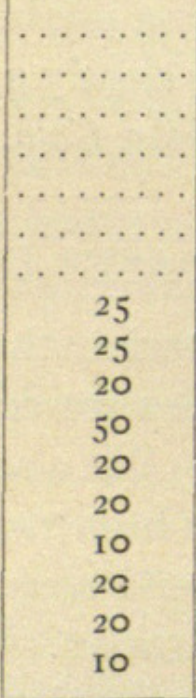 & 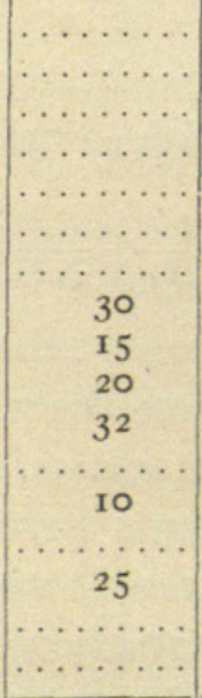 & \begin{tabular}{|l}
30 \\
33 \\
50 \\
13 \\
13 \\
20 \\
28 \\
20 \\
45 \\
20 \\
10 \\
50 \\
15 \\
15 \\
20 \\
$\ldots \ldots$ \\
25 \\
$\ldots \ldots$ \\
$\ldots \ldots$
\end{tabular} & $\begin{array}{l}36 \\
53 \\
46 \\
20 \\
40 \\
33 \\
28 \\
30 \\
30 \\
20 \\
40 \\
25 \\
20 \\
25 \\
\ldots \ldots \\
50 \\
30\end{array}$ \\
\hline Average....... & 60 & 45 & 22 & 22 & 26 & 33 \\
\hline
\end{tabular}

${ }^{2}$ It may be well to state that a new library card was taken each time for every quadrat study. The data were not tabulated or even looked at until the close of $\mathrm{rgr} 3$, lest the judgment of the observer at any time might be influenced by earlier records. 
The figures of 60 per cent bare ground for May 30 in table I should not be understood to mean that the other 40 per cent is fresh growth. Indeed, there is almost nothing green at that time of year. The vegetation cover is made up of the dry grasses, sedges, and flowering herbs of the previous summer. By July $\mathrm{I}$, however, the new growth has reached its maximum. This rapid development is necessitated by the shortness of the growing season. Only such plants as can mature quickly are able to exist under the rigorous climatic conditions.

TABLE II

Percentage of Bare ground in meadow grassland

\begin{tabular}{|c|c|c|c|c|c|c|}
\hline Quadrat & $\underset{\text { IgI } 2}{\text { May } 30}$ & $\begin{array}{c}\text { June } \text { I }_{2} \text {, } \\
\text { I } \mathrm{I}_{3}\end{array}$ & $\begin{array}{l}\text { June } 28, \\
\text { I9I3 }\end{array}$ & $\begin{array}{l}\text { July I } 2 \text {, } \\
\text { I913 }^{2}\end{array}$ & $\begin{array}{c}\text { July } 26 \text {, } \\
\text { I }^{2} \mathrm{I}_{3}\end{array}$ & 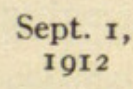 \\
\hline $\begin{array}{l}\mathrm{XI}(a) \ldots \ldots \ldots \ldots \\
\mathrm{XIII}(a) \ldots \ldots \ldots \ldots\end{array}$ & $\begin{array}{l}45 \\
25\end{array}$ & $\begin{array}{c}20 \\
\ldots \ldots \ldots\end{array}$ & $\begin{array}{r}0 \\
20\end{array}$ & $\begin{array}{r}0 \\
10\end{array}$ & $\begin{array}{r}0 \\
10\end{array}$ & $\begin{array}{l}\text { Io } \\
\text { Io }\end{array}$ \\
\hline Average....... & 35 & 20 & Io & 5 & 5 & IO \\
\hline
\end{tabular}

In the dry grassland, as will be seen from table I, there is a considerable proportion of bare ground, even at the height of the season in early July. The meadow association, on the other hand, shows little or no vacant space at that time. The differences depend chiefly on the texture of the soil, the finer grained material of the meadow holding more moisture and permitting more luxuriant growth.

It is interesting to note that when introduced weeds get a foothold in the region they do not become established in the open association of dry grassland, but in the already closely grown meadow.-Francis Ramaley, University of Colorado, Boulder, Colo.

\section{THE OXIDASES OF ACID TISSUES}

According to recent theories, the oxidases play an essential part in respiration. If these theories are correct, it follows that oxidases must be present in all organisms. But a serious difficulty is encountered in the fact that many plants have been reported to be free from oxidases. If this is really the case, it would seem that these theories must be abandoned, or at least greatly modified.

It appeared to the writer that in view of the importance of the subject a fresh investigation was needed. From the results of the writer's experiments it is evident that in many cases the reported absence of oxidases is to be ascribed to faulty methods of investigation. The 


\section{$2 \mathrm{BHL}$ Biodiversity Heritage Library}

Ramaley, Francis. 1914. "The Amount of Bare Ground in Some Mountain Grasslands." Botanical gazette 57(6), 526-528. https://doi.org/10.1086/331348.

View This Item Online: https://www.biodiversitylibrary.org/item/109459

DOI: https://doi.org/10.1086/331348

Permalink: https://www.biodiversitylibrary.org/partpdf/223583

\section{Holding Institution}

Missouri Botanical Garden, Peter H. Raven Library

\section{Sponsored by}

Missouri Botanical Garden

\section{Copyright \& Reuse}

Copyright Status: Public domain. The BHL considers that this work is no longer under copyright protection.

This document was created from content at the Biodiversity Heritage Library, the world's largest open access digital library for biodiversity literature and archives. Visit BHL at https://www.biodiversitylibrary.org. 